\title{
PENGEMBANGAN PERANGKAT PEMBELAJARAN MATEMATIKA YANG MENUNJANG PENDIDIKAN KARAKTER SISWA KELAS IV SEKOLAH DASAR
}

\section{DEVELOPING MATHEMATIC TEACHING KITS THAT SUPPORT THE CHARACTER EDUCATION OF THE STUDENTS IN CLASS V OF ELEMENTARY SCHOOLS}

\author{
Layin Fauziyah, Jailani \\ SD Muhammadiyah Bausasran II Yogyakarta, Universitas Negeri Yogyakarta \\ layinf@yahoo.com,jailani@uny.ac.id
}

\begin{abstract}
Abstrak
Penelitian ini bertujuan untuk menghasilkan perangkat pembelajaran matematika yang menunjang pendidikan karakter siswa kelas V sekolah dasar yang layak. Penelitian ini adalah penelitian pengembangan dengan menggunakan model pengembangan 4-D yang dikembangkan oleh Thiagarajan, Semmel \& Semmel yang telah dimodifikasi sehingga memuat tahapan define, design, dan develop. Produk yang dikembangkan adalah perangkat pembelajaran yang terdiri dari RPP, LKS, bahan ajar/buku siswa dan tes hasil belajar. Pengembangan perangkat pembelajaran dimulai dari tahap analisis awal-akhir, analisis peserta didik, analisis materi, analisis tugas, spesifikasi tujuan pembelajaran, pemilihan media, pemilihan format, validasi ahli, uji coba terbatas, uji coba lapangan, dan revisi. Instrumen penelitian yang digunakan terdiri dari lembar validasi, lembar observasi karakter siswa, dan lembar observasi kemampuan guru dalam mengelola pembelajaran untuk mengetahui keterlaksanaan RPP yang menunjang pendidikan karakter. Penelitian ini menghasilkan perangkat pembelajaran yang menunjang pendidikan karakter pada materi pecahan. Hasil validasi perangkat pembelajaran yang dikembangkan layak untuk digunakan dengan kategori cukup valid, praktis, dan efektif. Pembelajaran dengan menggunakan perangkat yang dikembangkan dapat membentuk karakter jujur, disiplin, dan bertanggung jawab. Berdasarkan pengamatan yang telah dilakukan, perangkat pembelajaran matematika yang dikembangkan pada uji coba terbatas dan uji coba lapangan menunjukkan peningkatan karakter siswa di setiap pertemuan.
\end{abstract}

Kata Kunci: pengembangan, perangkat pembelajaran, pendidikan karakter.

\begin{abstract}
This research aims to develop appropriate mathematic teaching kits that support the character education of the students in class $V$ of elementary school. This research is a research and development study using a model of the development of the 4-D developed by Thiagarajan, Semmel and Semmel which has been modified so that it consists of the defining, designing, and developing phases. The product developed is a teaching kit that consists of lesson plans, worksheets, instructional materials/students books, and a learning outcome test. The development is started from the initial stage-end analysis, analysis of learners, content analysis, task analysis, specification of learning objectives, media selection, format selection, test validation by experts, limited testing, field trials and revision. The instruments used in this study consisted of a validation sheet, students' character observation sheets, and observation sheets of teachers' capabilities in teaching management to determine the feasibility of the RPP that supports character education. The research produces a teaching kit that supports character education on the material about fractions. The results of the validation of the developed kit show that the teaching kit is feasible to use and it is valid, practical, and effective. The teaching using the developed kit can form honesty, discipline, and responsibility. Based on the observations that have been done, the developed mathematic teaching kit, according to the limited testing and field trials, shows the increase in the character of students in each meeting.
\end{abstract}

Keywords: development, learning kit, character education 


\section{Pendahuluan}

Fenomena merosotnya karakter manusia merupakan salah satu hal yang semakin hari semakin mendapat sorotan masyarakat Indonesia. Di berbagai media massa, hampir setiap hari terdengar santer berita tentang tindakan amoral yang melibatkan petinggi negara, masyarakat, dan siswa sekolah. Kasus korupsi, nepotisme, seks bebas, pembunuhan, dan pemerkosaan seolah-olah menjadi hal yang sudah biasa terjadi. Bahkan banyak juga terjadi penyimpangan yang dilakukan oleh siswa sekolah dasar, sebagai contoh di Kabupaten Gunungkidul tingkat bunuh diri cukup tinggi dan usia bunuh diri dari siswa SD (10 tahun) sampai 35 tahun sebagaimana telah diberitakan oleh Republika Online edisi 19 Desember 2010. Sekolah dasar sebagai peletak nilai dan norma mulai mengalami perubahan dengan adanya indikasi siswa melakukan berbagai penyimpangan. Sejalan dengan perkembangan zaman, segala sendi kehidupan mengalami perubahan, pada pendidikan dasar juga mengalami hal yang sama. Dampak perubahan dari pendidikan ada yang bermanfaat dan merugikan bagi masyarakat, hal ini dirasakan oleh masyarakat luas terutama berkaitan dengan sistem nilai, norma dan karakter. Pendidikan mempunyai posisi sebagai wahana yang harus bisa memberikan contoh kepada peserta didik untuk mengambil dampak positif dan meninggalkan dampak negatif dari globalisasi.

Pentingnya peran pendidikan dalam menghadapi perubahan zaman akibat globalisasi, maka pemerintah mengeluarkan UndangUndang dalam pasal I Sisdiknas tahun 2003 menyatakan bahwa di antara tujuan pendidikan nasional adalah mengembangkan potensi peserta didik untuk memiliki kecerdasan, kepribadian dan akhlak mulia. Amanah UU Sisdiknas tahun 2003 itu bermaksud agar pendidikan tidak hanya membentuk insan Indonesia yang cerdas, namun juga berkepribadian atau berkarakter, sehingga nantinya akan lahir generasi bangsa yang tumbuh berkembang dengan karakter yang bernafas nilai-nilai luhur bangsa serta agama.

Untuk mencapai tujuan tersebut disusun pula acuan operasional penyusunan Kurikulum Tingkat Satuan Pendidikan (KTSP) mengacu pada peningkatan keimanan dan ketaqwaan serta akhlaq yang mulia sehingga pendidikan karakter merupakan salah satu hasil dari kurikulum yang harus dilaksanakan dalam pendidikan di Indonesia. Diharapkan dengan adanya pendidikan karakter yang diterapkan secara sistematis dan berkelanjutan pada peserta didik nantinya peserta didik akan lebih bisa mengelola emosionalnya. Kecerdasan emosi inilah bekal penting bagi seseorang untuk kehidupan di masa datang karena seseorang lebih mudah dan berhasil menghadapi tantangan zaman.

Sistem pendidikan di Indonesia telah mengisyaratkan bahwa pembelajaran seharusnya menyeimbangkan aspek kognitif, afektif dan psikomotorik. Menurut Cohen (2006, p.201), "good of education need to be frame to prioritize not only academic learning but also social, emotional and ethnical competencies". Bahwa pendidikan yang baik perlu dibingkai untuk memprioritaskan tidak hanya belajar akademis saja tetapi juga kompetensi sosial, emosional dan etnik. Hal ini menurut Cohen sangat penting karena "it can help children reach the goal and their parents and teachers have for them: learning to read themselves and other, learning to solve social, emotional and ethical problem". Untuk mencapai tujuan, orang tua dan guru belajar membaca diri, belajar memecahkan masalah, emosi, dan etika.

Lickona (1991, pp.13-18) mengungkapkan bahwa ada sepuluh tanda-tanda jaman yang harus diwaspadai karena jika tanda-tanda ini sudah ada, maka berarti bahwa suatu bangsa sedang menuju jurang kehancuran. Tanda-tanda yang dimaksud adalah: (1) meningkatnya kekerasan di kalangan remaja, (2) penggunaan bahasa dan kata-kata yang memburuk, (3) pengaruh peer group yang kuat dalam tindak kekerasan, (4) meningkatnya perilaku merusak diri, seperti penggunaan narkoba, alkohol, dan seks bebas, (5) semakin kaburnya pedoman moral baik dan buruk, (6) menurunnya etos kerja, (7) semakin rendahnya hormat kepada orang tua dan guru, (8) rendahnya tanggung jawab individu dan warga negara, (9) membudayanya ketidakjujuran, (10) adanya rasa saling curiga dan kebencian diantara sesama. Kesepuluh hal inilah yang sedang menggejala di bangsa kita ini. Jadi sudah sepatutnya jika pendidikan sebagai tempat pembelajaran tentang nilai, moral, etika, karakter dan akhlaq yang peranannya sangat besar meski peran lingkungan dan keluarga jauh lebih besar, akan tetapi pada kenyataannya pembelajaran nilai, moral, etika, karakter dan akhlaq disekolah belum dilaksanakan secara optimal. 
Pada tahun 2012 praktik pendidikan di Indonesia masih banyak memprioritaskan kemampuan akademik saja dan jarang sekali membekali siswa untuk mengembangkan pendidikan karakter. Tidak heran jika banyak penyimpangan terjadi dalam dunia pendidikan seperti yang dilaporkan KOMPAS edisi 23 Desember 2011 bahwa terjadi peningkatan laporan tawuran pelajar, data Komnas Perlindungan Anak merilis jumlah tawuran pelajar tahun 2011 sebanyak 339 kasus dan memakan korban jiwa 82 orang. Selain itu, kesopanan dan akhlaq mulia siswa dinilai berkurang seperti apa yang dikemukakan oleh Supriadi Dwi (2012) menyatakan bahwa "wajar jika siswa memiliki perilaku yang menyimpang karena pendidikan yang berjalan cenderung sekedar transfer ilmu (transfer of knowledge) tidak diikuti dengan transfer nilai (transfer of value) yang memadai".

Berbagai contoh tindakan amoral yang terjadi, menunjukkan diperlukannya suatu pelindung yang sangat kuat. Pelindung tersebut yaitu karakter. Tanpa karakter sebagai landasan bersikap dan berperilaku, maka manusia hanya dipenuhi hawa nafsu. Peran karakter yaitu ibarat nahkoda dalam sebuah kapal. Karakter sebagai pengemudi yang akan menentukan arah benar salah ketika berlayar mengarungi lautan. Mengingat karakter penting untuk membangun kepribadian seseorang dan bangsa, pemerhati dan pelaku pendidikan menawarkan berbagai solusi, salah satunya yaitu pendidikan karakter. Tujuan utama pendidikan karakter adalah memfasilitasi penguatan dan pengembangan nilainilai sehingga dapat terwujud dalam perilaku anak baik ketika proses sekolah ataupun setelah lulus sekolah.

Selama ini pembelajaran mengenai etika, moral dan pendidikan karakter hanya dibebankan pada guru yang mengajar pendidikan kewarganegaraan dan pendidikan agama saja, sedangkan guru mata pelajaran seperti Bahasa Indonesia, Matematika, Ilmu Pengetahuan Alam mempunyai tugas hanya mengajarkan ilmu tersebut tanpa membantu peran guru yang mengajarkan etika, moral dan karakter. Dalam pedoman penyusunan KTSP sudah menyertakan pendidikan karakter namun masih terbatas pada penanaman kebiasaan berpikir dan berperilaku ilmiah yang kritis, kreatif dan mandiri. Hal ini belum sesuai dengan yang diharapkan Kementerian Pendidikan Nasional Badan Pendidikan dan Pengembangan yang menyampaikan bahwa nilai pendidikan karakter ada 18 jenis karakter. Oleh karena itu guru selaku pendidik hendaknya harus pandai dalam mensinergikan pendidikan karakter ini dengan semua mata pelajaran termasuk pelajaran matematika. Hal ini terjadi juga di SD Negeri Kecamatan Danurejan belum ada pendidikan karakter dalam pembelajaran matematika khususnya di kelas V. Selain itu juga didalam Rencana Persiapan Pembelajaran (RPP) sudah disiapkan pendidikan yang menunjang berkembangnya karakter namun karena terbatasnya pengetahuan dan pengalaman dalam pembelajaran matematika SD Negeri di wilayah Kecamatan Danurejan khususnya kelas $\mathrm{V}$ belum dilaksanakan dengan baik dan benar sesuai dengan apa yang diinginkan oleh Undang-Undang No. 20 tahun 2003.

Sementara ini masih banyak guru dalam menyampaikan pembelajaran matematika belum atau jarang sekali memberikan muatan nilai pendidikan karakter terhadap materi yang disampaikan. Para guru dalam melaksanakan proses belajar dan mengajar terkesan tanpa makna. Guru dalam menyampaikan materi matematika terlalu abstrak sehingga membuat siswa tidak berminat, pembelajaran matematika masih dirasa kering dengan makna dan kosong akan nilai pendidikan karakter serta berfikir bahwa pelajaran metematika tidak bisa untuk menanamkan karakter (kedisiplinan, kejujuran dan tanggung jawab). Banyak siswa yang juga belum memahami arti pentingnya matematika dalam sebuah kehidupan dan tidak tahu untuk apa harus belajar matematika yang berakibat pada kurang berminatnya anak-anak terhadap pelajaran tersebut, matematika dianggap pelajaran yang terlalu abstrak, siswa belum memahami apa manfaat matematika dalam kehidupan sehari-hari. Banyak ditemui dalam pembelajaran matematika siswa mudah lupa (karena abstrak) bahkan tidak tahu akan memulai dari mana bila belajar matematika.

Dalam pembelajaran matematika, guru biasanya hanya sampai pada "learning to do" yaitu siswa bisa menyelesaikan soal saja tapi belum sampai pada "learning to mean" kebermaknaan dari matematika itu sendiri. Padahal ilmu matematika memiliki tujuan baik jangka pendek maupun jangka panjang. Tujuan jangka pendek agar siswa memahami materi matematika yang dipelajarinya dan dapat mempergunakan pada pelajaran lain, sedang tujuan jangka panjangnya adalah agar siswa dapat mengambil nilai-nilai matematika dan mengaplikasikan dalam kehidupan yang sebenarnya. 
Diantara nilai-nilai karakter yang dapat ditanamkan dalam pelajaran matematika adalah kejujuran, kedisiplinan dan bertanggungjawab. Dalam pembelajaran matematika nilai-nilai karakter tersebut siswa perlu memiliki kemampuan memperoleh, memilih dan mengelola informasi untuk bertahan pada keadaan yang selalu berubah (survive), ketidak pastian dan hidup serba kompetitif. Kemampuan tersebut membutuhkan pemikiran kritis, sistematis, logis dan kreatif untuk bekerjasama yang efektif. Cara berpikir seperti ini juga dapat dikembangkan melalui belajar matematika.

Adanya kasus-kasus yang sering terjadi di SD Negeri wilayah Kecamatan Danurejan berupa anak suka berkata bohong, tidak mengerjakan PR, tidak mengerjakan tugas sekolah, datang ke sekolah terlambat, kelas kotor karena siswa tidak piket, tidak melaksanakan tata tertib sekolah, kehilangan barang, membayar jajanan di kantin tidak sesuai dengan harga yang seharusnya, dan masih banyak penyimpangan perilaku anak usia SD karena lunturnya moral. Mungkin ini dipengaruhi adanya tayangan televisi yang berupa sinetron-sinetron yang tidak mendidik, menayangkan kebohongankebohongan dengan keadaan yang sebenarnya serta pengaruh berita di koran yang isinya tentang perilaku melanggar norma agama ataupun norma masyarakat, demikian juga dengan pengaruh media internet/dunia maya dimana dengan membuka internet akan didapat informasi apapun yang diinginkan. Sebagai pendidik dan sekaligus sebagai pemirsa televisi bersepakat bahwa acara musik, sinetron, iklan, dan tayangan-tayangan tidak mendidik yang dapat membuat anak menggunakan bahasa gaul (menyimpang) berkata kotor seperti 'anjing', 'kurang ajar', 'matamu' menjadi sangat familier, trend semacam ini adalah hasil anak-anak meniru para artis dalam tayangan televisi yang tidak mengerti maknanya, sekedar mengikuti mode.

Pemikiran tentang pelajaran matematika dapat dijadikan sebagai wahana untuk pengembangan pendidikan karakter. Desain pembelajaran yang sudah mengimplementasikan pendidikan karakter di dalamnya dapat digunakan dengan baik oleh pendidik untuk kemudian dapat menghasilkan peserta didik yang berkarakter.

\section{Metode Penelitian}

Jenis Penelitian dan Model Pengembangan

Penelitian ini merupakan penelitian pengembangan yaitu suatu proses yang digunakan untuk mengembangkan atau menvalidasi produk-produk yang digunakan dalam pendidikan dan pembelajaran hal tersebut dikemukakan oleh Borg dan Gall (1983, p. 472). Pada dasarnya ada dua tujuan utama dalam penelitian pengembangan yaitu: (1) mengembangkan produk, (2) memvalidasi produk yang dihasilkan.

Penelitian ini difokuskan pada pengembangan produk berupa perangkat pembelajaran matematika yang menunjang pendidikan karakter. Perangkat yang dikembangkan adalah bahan Ajar atau buku siswa, Rencana Pelaksanaan Pembelajaran (RPP), Lembar Kegiatan Siswa (LKS) dan tes hasil belajar.

Model pengembangan perangkat pembelajaran mengacu pada model 4-D yang dikembangkan oleh Thiagarajan, Semmel \& Semmel yang memuat proses Define, Design, Development, dan Dissemination. Penelitian yang dilakukan hanya sampai pada development saja, dikarenakan adanya keterbatasan tenaga, waktu dan biaya yang harus dilakukan peneliti.

Waktu dan Tempat Penelitian

Penelitian ini dimulai pada bulan April sampai dengan Mei tahun 2013 dan dilakukan di Sekolah Dasar Negeri Lempuyangan I dan Sekolah Dasar Negeri Tegal Panggung Kecamatan Danurejan Kota Yogyakarta.

\section{Subjek Penelitian}

Subjek uji coba terbatas dalam penelitian pengembangan ini adalah siswa kelas $\mathrm{V}$ Sekolah Dasar Negeri Lempuyangan I sedangkan subjek uji coba lapangan adalah siswa kelas V Sekolah Dasar Negeri Tegal Panggung Kecamatan Danurejan Kota Yogyakarta.

\section{Prosedur Pengembangan}

Prosedur pengembangan dalam penelitian ini diadaptasi dari model pengembangan menurut Thiagarajan, Semmel \& Semmel yang dikenal sebagai model 4-D yang telah di modifikasi menjadi 3-D. Penelitian pengembangan yang dilakukan dalam penelitian ini meliputi tiga tahap yaitu tahap define (pendefinisian), tahap design (perancangan), dan tahap development (pengembangan). 


\section{Tahap Define (Pendefinisian)}

Tahap ini meliputi lima langkah pokok yaitu: Analisis awal-akhir, dilakukan untuk mengetahui masalah dasar dalam pengembangan perangkat pembelajaran. Tahap ini mengadakan analisis kurikulum yang berguna untuk mengetahui SK dan KD yang menjadi dasar penyusunan RPP, bahan ajar, LKS dan tes hasil belajar. Analisis siswa, dilakukan untuk mengetahui karakteristik peserta didik yang dijadikan sasaran penelitian. Karakter disini bisa karakter sekolah maupun karakter peserta didik. Analisis materi untuk mengidentifikasi, merinci dan menyusun secara sistematis bagian utama yang akan diajarkan pada peserta didik. Analisis tugas bertujuan untuk mengidentifikasi tugas yang akan dilaksanakan peserta didik dalam pembelajaran dan dalam analisis tugas mencakup pendalaman materi dan pencapaian hasil belajar. Analisis ini sebagai dasar merumuskan indikator pencapaian hasil belajar dan nilai karakter yang dikembangkan dalam kegiatan pembelajaran. Spesifikasi tujuan belajar untuk merumuskan indikator-indikator pencapaian hasil belajar berdasarkan analisis materi dan analisis tugas. Perumusan indikator pencapaian hasil belajar merupakan dasar untuk mengetahui kajian tentang apa saja yang akan di tampil dalam perangkat pembelajaran dan akhirnya dapat menentukan seberapa besar tujuan pembelajaran dapat tercapai.

Tahap Design (Perancangan)

Tahap perancangan ini meliputi 3 langkah, yaitu langkah pemilihan media, hal ini berkaitan dengan penentuan media yang paling tepat untuk menyajikan materi pelajaran yang didasarkan pada analisis materi, analisis tugas dan fasilitas yang disediakan oleh sekolah serta karakteristik peserta didik. Pemilihan format untuk merancang isi materi, pemilihan strategi, pendekatan dan metode pembelajaran serta sumber belajar yang dikembangkan. Perancangan awal dengan kegiatan menyusun RPP, bahan ajar, LKS dan tes hasil belajar. Lembar observasi karakter siswa dan lembar observasi kemampuan guru dalam mengelola pembelajaran

\section{Tahap Development (Pengembangan)}

Sebelum dilaksanakan uji coba untuk mengetahui kelayakan produk perlu mendapatkan validasi dari ahli materi. Validasi lembar instrumen dilakukan oleh dosen MIPA Universitas Negeri Yogyakarta, dosen yang terlibat dalam validasi ini adalah Rosnawati, M.Si, sedangkan validasi produk dilakukan oleh dosen MIPA dan dosen pendidikan dasar Program Pasca Sarjana Universitas Negeri Yogyakarta, dosen yang terlibat adalah Drs. Edy Prajitno, M.Pd dan Dr. Ali Mustadi, M.Pd. Masingmasing dosen ahli tersebut memberikan validasi terhadap produk secara terstruktur dengan memberikan data kualitatif berupa lembar validasi dan tidak terstruktur berupa catatan dan komentar serta masukan-masukan secara lisan pada saat konsultasi validasi. Tujuan dari kegiatan ini untuk mendapatkan penguatan dari ahli terhadap perangkat pembelajaran yang telah dikembangkan.

Pada tahap ini dilaksanakan dengan menyerahkan produk yang dikembangkan untuk dinilai dengan lembar instrumen penilaian materi. Validasi juga dimaksudkan untuk mengetahui aspek kebenaran dan kelayakan baik dari segi atau sisi materi. Validasi dari ahli materi tersebut digunakan untuk mengetahui kualitas produk yang dikembangkan.

Setelah produk awal dinyatakan valid kemudian produk yang telah dikembangkan siap untuk digunakan dalam uji coba terbatas. Uji coba terbatas dilakukan di SD Negeri Lempuyangan I Kecamatan Danurejan Kota Yogyakarta kelas $\mathrm{V}$ yang terdiri dari 8 orang siswa. Dari ke delapan orang siswa tersebut dipilih 2 orang yang mewakili tingkat prestasi tinggi, 3 orang dengan tingkat prestasi sedang, dan 3 orang dengan tingkat prestasi rendah, penentuan ini berdasarkan rangking pada semester 1 . Dalam uji coba terbatas ini siswa diberikan kesempatan untuk membaca dan mempelajari produk buku yang dikembangkan. Uji coba terbatas ini bertujuan untuk melihat apakah terdapat kelemahan-kelemahan yang terdapat dalam bahan ajar, LKS dan tes hasil belajar. Setelah uji coba terbatas kemudian produk direvisi kembali berdasarkan kelemahankelemahan yang ditemukan pada saat uji coba terbatas.

Setelah uji coba terbatas di revisi maka dilakukan uji coba lapangan yaitu melakukan pembelajaran matematika di SD Negeri Tegal Panggung Kecamatan Danurejan Kota Yogyakarta pada siswa kelas $\mathrm{V}$ dengan menggunakan produk yang dikembangkan. Uji coba lapangan ini dimaksudkan untuk memperoleh respons, umpan balik terhadap bahan ajar yang telah dikembangkan dan juga melihat efektivitas produk. Apabila respons sasaran pengguna bahan ajar sudah baik maka produk akhir dari 
penelitian pengembangan ini dapat digunakan dalam proses pembelajaran di kelas V Sekolah Dasar.

Uji lapangan ini dilakukan di kelas $\mathrm{V}$ yang terdiri dari 32 orang siswa. Uji coba lapangan ini berlangsung selama 5 kali pertemuan, selama kurun waktu tersebut siswa dan guru menggunakan produk RPP, bahan ajar, LKS dan tes hasil belajar. Sebelum produk digunakan dalam proses pembelajaran terlebih dahulu siswa diberikan soal tes hasil belajar sebagai pretest untuk melihat kemampuan awal siswa sebelum menggunakan produk. Setelah melakukan proses pembelajaran dengan menggunakan produk yang dikembangkan kemudian siswa diberikan soal tes hasil belajar sebagai posttest untuk melihat sejauh mana pemahaman materi dapat dikuasai oleh siswa.

Hasil dari perhitungan pretest dan posttest inilah yang akan menentukan efektivitas produk yang dikembangkan. Apabila skor nilai gain menunjukkan kategori tinggi maka produk yang dikembangkan dikatakan efektif. Sehingga produk akhir dari proses pengembangan perangkat pembelajaran matematika yang menunjang pendidikan karakter kelas $\mathrm{V}$ ini sudah dapat digunakan sebagai salah satu bahan ajar pembelajaran di kelas V.

\section{Jenis Data dan Instrumen Pengumpulan Data}

Data yang akan diperoleh dalam penelitian ini berupa data kualitatif dan data kuantitatif. Data kualitatif diperoleh dari komentar dan tanggapan siswa, guru, dan ahli materi. Data kuantatif diperoleh dari hasil pengisian lembar validasi ahli materi, dan respons peserta didik serta data hasil belajar siswa dari soal tes hasil belajar sebagai pretest dan posttest. Instrumen yang digunakan untuk mengumpulkan data pada penelitian pengembangan ini berupa lembar validasi ahli materi, lembar observasi karakter siswa, lembar kemampuan guru dalam pembelajaran. Instrumen yang dimaksudkan tersebut digunakan untuk mengevaluasi kualitas produk perangkat pembelajaran matematika yang menunjang pendidikan karakter dan untuk mengetahui efektivitas perangkat pembelajaran matematika yang menunjang pendidikan karakter dilihat dari peningkatan hasil belajar siswa dalam proses pembelajaran dengan menggunakan produk yang telah dikembangkan.

Teknik Analisis Data

Data kualitatif dalam penelitian ini berupa kritik dan saran yang dikemukakan ahli materi. Data-data ini dihimpun dan disarikan untuk memperbaiki produk perangkat pembelajaran matematika yang menunjang pendidikan karakter yang telah dikembangkan. Sedangkan data kuantitatif berupa skor pada masingmasing butir instrumen yang telah diisi oleh ahli materi dan data pretest dan posttest pada pelaksanaan uji coba terbatas dan uji coba lapangan.

\section{Analisis Kelayakan atau Hasil Validasi ahli}

Teknik yang digunakan untuk memberikan kriteria nilai kualitas produk yang dikembangkan yaitu (1) data yang diperoleh dari angket diubah dulu menjadi data interval seperti tersaji pada tabel 1 berikut:

Tabel 1. Kriteria Penskoran Item pada Angket

\begin{tabular}{cc}
\hline Kriteria & Skor \\
\hline Sangat Baik & 5 \\
Baik & 4 \\
Cukup Baik & 3 \\
Kurang Baik & 2 \\
Sangat Kurang Baik & 1 \\
\hline
\end{tabular}

Skor yang diperoleh kemudian dijumlahkan dan dirata-ratakan, selanjutnya dikonversikan menjadi nilai pada skala 5, hal ini sesuai dengan acuan tabel yang diadaptasi dari Sukardjo (2010, pp.100-101) seperti tersaji pada tabel 2 dibawah ini:

Tabel 2. Konversi Skor menjadi Kriteria pada Skala Lima

\begin{tabular}{|c|c|c|}
\hline Nilai & Interval Skor & Kriteria \\
\hline $\mathrm{A}$ & $-\mathrm{X}>\bar{X}_{\bar{i}}+1,80 \mathrm{SB}_{\underline{i}}$ & Sangat Baik \\
\hline B & $\begin{array}{c}\bar{X}_{\tilde{i}}+0,60 \mathrm{SB}_{\mathrm{i}}<\mathrm{X} \leq \bar{X}_{\mathrm{i}}+ \\
1,80 \mathrm{SB}_{\mathrm{i}}\end{array}$ & Baik \\
\hline $\mathrm{C}$ & $\begin{array}{c}\bar{X}_{\bar{i}}-0,60 \mathrm{SB}_{\mathrm{i}}<\mathrm{X} \leq \bar{X}_{\overline{\mathrm{i}}}+ \\
0,60 \mathrm{SB}_{\mathrm{i}}\end{array}$ & Cukup \\
\hline D & $\begin{array}{c}\bar{X}_{\bar{i}}-1,80 \mathrm{SB}_{\mathrm{i}}<\mathrm{X} \leq \bar{X}_{\bar{i}}+ \\
0,60 \mathrm{SB}_{\mathrm{i}}\end{array}$ & Kurang \\
\hline $\mathrm{E}$ & $\mathrm{X} \leq \bar{X}_{\overline{\mathrm{i}}}-1,80 \mathrm{SB}_{\mathrm{i}}$ & $\begin{array}{l}\text { Sangat } \\
\text { Kurang }\end{array}$ \\
\hline
\end{tabular}

Analisis Hasil Tes Hasil Belajar

Untuk mengetahui efektivitas produk berupa tingkat pemahaman materi yang telah diajarkan diwujudkan dalam skor tes hasil belajar. Data pretest dan posttest hasil belajar dianalisis dengan membandingkan skor pretest dan skor posttest. Peningkatan yang terjadi sebelum kegiatan pembelajaran dengan menggunakan produk yang dikembangkan dan sesudah pembelajaran dengan menggunakan produk yang dikembangkan diperhitungkan dengan 
rumus (N-gain) yang ditentukan berdasarkan rata-rata gain skor yang dinormalisasi (g) yaitu perbandingan dari skor gain. Skor gain yaitu skor gain yang diperoleh siswa pretest dan Posttest sedangkan skor gain maksimum yaitu skor gain tertinggi yang diperoleh siswa. Ratarata gain yang dinormalisasi (N-Gain) (Hake, 1998 , p. 2) dinyatakan oleh persamaan sebagai berikut:

$\mathrm{g}=\frac{\text { Spost }- \text { Spre }}{\text { Smaks-Spre }}$

Keterangan :

S-Post : Skor Posttest

S-Pre : Skor Pretest

S-Maks: Skor Maksimal

Nilai ini kemudian diinterpretasikan ke dalam Tabel 3 yaitu klasifikasi Nilai Gain (Hake, 1998, p.3) sebagai berikut:

Tabel 3. Klasifikasi Nilai Gain

\begin{tabular}{cc}
\hline Nilai $(\mathbf{g})$ & Klasifikasi \\
\hline$(\mathrm{N}-$ gain $) \geq 0,7$ & Tinggi \\
$0,7>(\mathrm{N}-$ gain $) \geq 0,3$ & Sedang \\
$(\mathrm{N}-$ gain $)<0,3$ & Rendah \\
\hline
\end{tabular}

\section{Hasil Penelitian dan Pembahasan}

\section{Analisis Data Hasil Validasi Ahli Materi}

Dalam analisis data hasil validasi produk ahli materi ini terdapat empat perangkat yang dikembangkan yaitu RPP, bahan ajar, LKS dan tes hasil belajar. Hasil validasi dari ahli materi sebagai berikut:

Tabel 4. Rekap hasil validasi ahli

\begin{tabular}{ccc}
\hline Perangkat & Ahli I & Ahli II \\
\hline RPP & 75 & 119 \\
Bahan Ajar & 44 & 59 \\
LKS & 45 & 55 \\
Tes Hasil Belajar & 35 & 49 \\
\hline
\end{tabular}

Rencana Pelaksanaan Pembelajaran (RPP)

Hasil validasi dari kedua ahli materi dapat dilihat secara rinci di bawah ini:

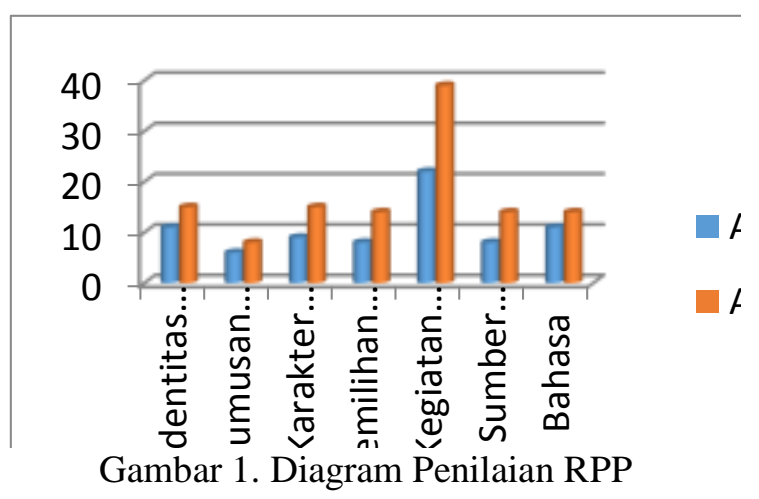

Berdasarkan diagram penilaian ahli materi terhadap produk yang dikembangkan diketahui bahwa penilaian ahli materi terhadap aspek identitas mata pelajaran mendapat nilai sebesar 11 dan 15, rumusan indicator sebesar 6 dan 8 , karakter yang diharapkan sebesar 9 dan 15 , pemilihan materi sebesar 8 dan 14, kegiatan pembelajaran sebesar 22 dan 39, sumber belajar 8 dan 14 dan bahasa sebesar 11 dan 14. Penilaian ahli materi tersebut termasuk dalam kategori cukup dan sangat baik, sehingga dapat dikatakan bahwa perangkat pembelajaran matematika yang menunjang pendidikan karakter sudah memenuhi syarat yang baik sebagai sebuah RPP yang boleh digunakan oleh guru matematika.

Bahan Ajar

Hasil validasi dari kedua ahli materi dapat dilihat di bawah ini:

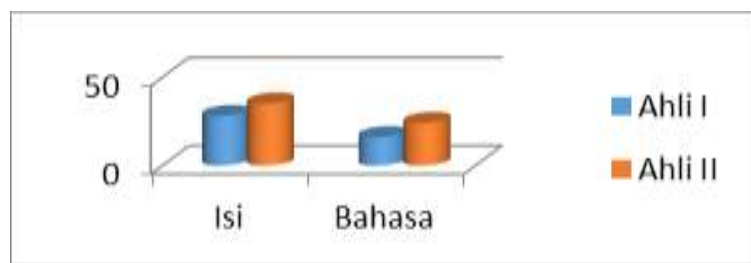

Gambar 2. Diagram Penilaian Bahan Ajar

Berdasarkan hasil penilaian tersebut dapat dinyatakan bahwa menurut ahli I, bahan ajar yang dikembangkan mendapatkan nilai 44 dengan kategori baik, sedangkan ahli II menunjukkan bahwa bahan ajar hasil pengembangan dari aspek isi mendapatkan skor total 35, dan aspek bahasa mendapatkan skor total 24.

Lembar Kegiatan Siswa (LKS)

Berdasarkan data yang diperoleh dari hasil validasi oleh ahli I menunjukkan bahwa LKS hasil pengembangan dari aspek isi mendapatkan skor total 29, dan aspek bahasa mendapatkan skor total 16. LKS yang dikembangkan mendapatkan nilai 45 dengan kategori baik. 
Berdasarkan data yang diperoleh dari hasil validasi oleh ahli II menunjukkan bahwa LKS hasil pengembangan dari aspek isi mendapatkan skor total 33, dan aspek bahasa mendapatkan skor total 22. LKS yang dikembangkan mendapatkan nilai 55 dengan kategori sangat baik.

Hasil validasi dari kedua ahli materi dapat dilihat di bawah ini:

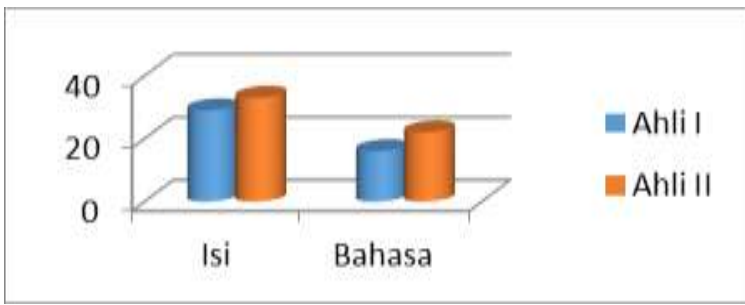

Gambar 3. Diagram Penilaian LKS

Tes Hasil Belajar (THB)

Berdasarkan data yang diperoleh dari hasil validasi oleh ahli I menunjukkan bahwa tes hasil belajar hasil pengembangan dari aspek tehnis penilaian mendapatkan skot total 7 , isi mendapatkan skor total 16, dan aspek bahasa mendapatkan skor total 12. Hasil skor total penilaian tersebut dapat dinyatakan bahwa menurut ahli I, tes hasil belajar yang dikembangkan mendapatkan nilai 35 dengan kategori cukup baik.

Berdasarkan data yang diperoleh dari hasil validasi oleh ahli II menunjukkan bahwa tes hasil belajar hasil pengembangan dari aspek tehnis penilaian mendapatkan skot total 9, isi mendapatkan skor total 19, dan aspek bahasa mendapatkan skor total 21. Hasil skor total penilaian tersebut dapat dinyatakan bahwa menurut ahli II, tes hasil belajar yang dikembangkan mendapatkan nilai 49 dengan kategori sangat baik.

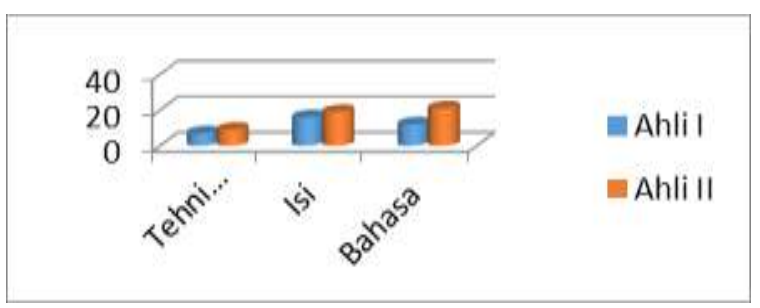

Gambar 4. Diagram Penilaian THB

\section{Analisis Data Hasil Uji Coba Terbatas}

Uji coba terbatas dilakukan pada siswa kelas V Sekolah Dasar Negeri Lempuyangan 1 sebanyak 8 orang siswa. Pemilihan subjek uji coba dilakukan dengan membagi siswa ke dalam kategori prestasi tinggi, sedang, dan rendah. Tujuan uji coba terbatas adalah untuk mengumpulkan informasi yang dapat digunakan sebagai bahan untuk merevisi atau memperbaiki produk untuk digunakan dalam uji coba lapangan serta melihat efektivitas produk dalam pembelajaran.

\section{Data Ketercapaian Pembentukan Karakter}

Pengukuran terhadap pembentukan karakter peserta didik berdasarkan pada data lembar observasi karakter. Skor aktual yang diperoleh peserta didik merupakan pengamatan yang telah dilakukan oleh pengamat. Secara keseluruhan hasil ketercapaian pendidikan karakter dalam uji coba terbatas adalah:

Tabel 5. Rekap Ketercapaian Pembentukan Karakter

\begin{tabular}{cccc}
\hline Karakter & I & II & III \\
\hline Kejujuran & 37,5 & 100 & 100 \\
Kedisiplinan & 25 & 100 & 100 \\
Tanggungjawab & 62,5 & 100 & 100 \\
\hline
\end{tabular}

\section{Karakter Jujur}

Data hasil pembentukan karakter jujur pada uji coba terbatas secara rinci dapat dilihat pada tabel 6 .

Tabel 6. Hasil Pengamatan Karakter Jujur

\begin{tabular}{ccc}
\hline Pertemuan & $\begin{array}{c}\text { Persentase } \\
(\boldsymbol{\%})\end{array}$ & $\begin{array}{c}\text { Karakter siswa } \\
\text { yang mencapai } \\
\text { kategori baik (\%) }\end{array}$ \\
\hline I & 73 & 37,5 \\
II & 83 & 100 \\
III & 100 & 100 \\
\hline
\end{tabular}

Berdasarkan tabel 6 tersebut dapat disimpulkan bahwa perangkat pembelajaran yang dikembangkan sudah efektif, baik karena persentase siswa yang memenuhi kategori karakter jujur yang diharapkan 'baik' pada setiap pertemuan.

\section{Karakter Disiplin}

Data hasil pengamatan pembentukan karakter disiplin pada uji coba terbatas dapat dilihat pada tabel 7 .

Tabel 7. Hasil pengamatan karakter disiplin

\begin{tabular}{ccc}
\hline & $\begin{array}{c}\text { Persentase } \\
(\%)\end{array}$ & $\begin{array}{c}\text { Karakter siswa } \\
\text { yang mencapai } \\
\text { kategori baik }(\%)\end{array}$ \\
\hline I & 71 & 25 \\
II & 88 & 100 \\
III & 100 & 100 \\
\hline
\end{tabular}

Berdasarkan tabel 7 tersebut dapat disimpulkan bahwa perangkat pembelajaran 
yang dikembangkan sudah efektif, baik karena persentase siswa yang memenuhi kategori karakter disiplin yang diharapkan 'baik' pada setiap pertemuan.

\section{Karakter Tanggung Jawab}

Data hasil pengamatan pembentukan karakter tanggungjawab pada uji coba terbatas dapat dilihat pada tabel 8 .

Tabel 8. Hasil Pengamatan Karakter Tanggung Jawab

\begin{tabular}{ccc}
\hline Pertemuan & $\begin{array}{c}\text { Persentase } \\
(\boldsymbol{\%})\end{array}$ & $\begin{array}{c}\text { Karakter siswa yang } \\
\text { mencapai kategori } \\
\text { baik }(\boldsymbol{\%})\end{array}$ \\
\hline I & 75 & 62,5 \\
II & 92 & 100 \\
III & 100 & 100 \\
\hline
\end{tabular}

Berdasarkan tabel 8 tersebut dapat disimpulkan bahwa perangkat pembelajaran yang dikembangkan sudah efektif, baik karena persentase siswa yang memenuhi kategori karakter tanggungjawab yang diharapkan 'baik' pada setiap pertemuan.

\section{Data Keterlaksanaan RPP}

Data hasil pengamatan keterlaksanaan RPP pada uji coba terbatas dapat di lihat pada tabel 9.

Tabel 9. Rekap keterlaksanaan RPP

\begin{tabular}{lccc}
\hline \multirow{2}{*}{\multicolumn{1}{c}{ Penilaian }} & \multicolumn{3}{c}{ Pertemuan } \\
\cline { 2 - 4 } & I & II & III \\
\hline Terlaksana & 18 & 23 & 25 \\
Tdk terlaksana & 7 & 2 & - \\
\% keterlaksanaan & 72 & 92 & 100 \\
\hline
\end{tabular}

Data Tes Hasil Belajar

Data tes hasil belajar uji coba terbatas diperoleh dari nilai pretest dan posttest control design, sehingga penilaian dilakuakan 2 kali yaitu sebelum diberikan perlakuan (pretest) dan sesudah perlakuan (posttest). Tujuan desain ini adalah untuk mengetahui ada tiaknya pengaruh dan seberapa besar pengaruh perlakuan terhadap peningkatan karakter siswa.

Tabel 10. Hasil Pretest dan Posttest Uji Coba Terbatas

\begin{tabular}{|c|c|c|c|c|c|}
\hline \multirow{2}{*}{ No } & \multirow{2}{*}{ Nama } & \multicolumn{2}{|c|}{ Nilai } & \multirow{2}{*}{ Indeks Gain } & \multirow{2}{*}{ Kriteria } \\
\hline & & Pretest & Posttest & & \\
\hline 1 & AA & 56 & 86 & 0,68 & Sedang \\
\hline 2 & $\mathrm{AB}$ & 46 & 78 & 0,59 & Sedang \\
\hline 3 & $\mathrm{AC}$ & 62 & 82 & 0,53 & Sedang \\
\hline 4 & $\mathrm{AD}$ & 72 & 96 & 0,86 & Tinggi \\
\hline 5 & $\mathrm{AE}$ & 66 & 92 & 0,76 & Tinggi \\
\hline 6 & $\mathrm{AF}$ & 66 & 94 & 0,82 & Tinggi \\
\hline 7 & $\mathrm{AG}$ & 54 & 80 & 0,57 & Sedang \\
\hline 8 & $\mathrm{AH}$ & 52 & 92 & 0,83 & Tinggi \\
\hline \multicolumn{2}{|c|}{ Total } & 474 & 700 & \multirow{4}{*}{0,71} & \multirow{4}{*}{ Tinggi } \\
\hline \multicolumn{2}{|c|}{ Rata-rata } & 59,25 & 87,5 & & \\
\hline & inggi & 72 & 96 & & \\
\hline & endah & 46 & 78 & & \\
\hline
\end{tabular}

Data yang dihasilkan dalam uji coba terbatas ini berupa masukan dan saran dari pendidik yang menilai RPP, bahan ajar/buku siswa serta masukan dan saran dari siswa tentang keterbacaan LKS. Dari masukan dan saran guru dan siswa tersebut selanjutnya dijadikan dasar untuk dilakukan revisi terhadap perangkat pembelajaran.

\section{Analisis Data Hasil Uji Coba Lapangan}

Subjek uji coba lapangan adalah siswa kelas V SD Negeri Tegal Panggung yang tepat- nya terletak di Kalurahan Tegal Panggung. Kelas $\mathrm{V}$ yang dipilih sebagai subjek uji coba berbeda kemampuan awal prestasi dan karakter. Seperti halnya dalam uji coba terbatas pada pelaksanaan uji coba lapangan di peroleh data untuk mengukur efektifitas perangkat pembelajaran yang dikembangkan. Selain mengukur kualitas dan efektifitas produk yang dikembangkan, uji coba juga untuk mengetahui pengaruh penggunaan produk yang dikembangkan. Secara keseluruhan hasil ketercapaian 
pendidikan karakter dalam uji coba terbatas adalah:

Tabel 11. Rekap ketercapaian pembentukan karakter

\begin{tabular}{cccc}
\hline Karakter & I & II & III \\
\hline Kejujuran & 43 & 100 & 100 \\
Kedisiplinan & 52 & 100 & 100 \\
Tanggungjawab & 60 & 100 & 100 \\
\hline
\end{tabular}

\section{Data Ketercapaian Pembentukan Karakter}

Pada aspek karakter ini di analisis menggunakan lembar observasi karakter pesrta didik dengan mengamati secara langsung aktivitas siswa yang sesuai dengan nilai-nilai karakter. Data nilai pendidikan karakter siswa selama proses pembelajaran diteliti dengan tujuan untuk mengetahui sejauh mana aktivitas siswa yang sejalan dengan karakter kejujuran, kedisiplinan dan tanggungjawab selama pembelajaran berlangsung.

\section{Karakter Jujur}

Data hasil pembentukan karakter jujur pada uji coba terbatas dapat dilihat pada tabel 12.

Tabel 8. Hasil Pengamatan Karakter Jujur

\begin{tabular}{ccc}
\hline Pertemuan & $\begin{array}{c}\text { Persentase } \\
(\%)\end{array}$ & $\begin{array}{c}\text { Karakter siswa yang } \\
\text { mencapai kategori } \\
\text { baik (\%) }\end{array}$ \\
\hline I & 72 & 43 \\
II & 93 & 100 \\
III & 100 & 100 \\
\hline
\end{tabular}

Berdasarkan tabel 12 tersebut dapat disimpulkan bahwa perangkat pembelajaran yang dikembangkan sudah efektif, baik karena persentase siswa yang memenuhi kategori karakter jujur yang diharapkan 'baik' pada setiap pertemuan.

\section{Karakter Disiplin}

Data hasil pengamatan pembentukan karakter disiplin pada uji coba terbatas dapat dilihat pada tabel 13.
Tabel 13. Hasil Pengamatan Karakter Disiplin

\begin{tabular}{ccc}
\hline Pertemuan & $\begin{array}{c}\text { Persentase } \\
(\boldsymbol{\%})\end{array}$ & $\begin{array}{c}\text { Karakter siswa yang } \\
\text { mencapai kategori } \\
\text { baik }(\boldsymbol{\%})\end{array}$ \\
\hline I & 73 & 52 \\
II & 95 & 100 \\
III & 100 & 100 \\
\hline
\end{tabular}

Berdasarkan tabel 13 tersebut dapat disimpulkan bahwa perangkat pembelajaran yang dikembangkan sudah efektif, baik karena persentase siswa yang memenuhi kategori karakter disiplin yang diharapkan 'baik' pada setiap pertemuan.

3. Karakter Tanggung jawab

Data hasil pengamatan pembentukan karakter tanggung jawab pada uji coba terbatas dapat dilihat pada tabel 14.

Tabel 14. Hasil Pengamatan Karakter Tanggung Jawab

\begin{tabular}{ccc}
\hline Pertemuan & $\begin{array}{c}\text { Persentase } \\
(\%)\end{array}$ & $\begin{array}{c}\text { Karakter siswa yang } \\
\text { mencapai kategori } \\
\text { baik }(\%)\end{array}$ \\
\hline I & 76 & 60 \\
II & 97 & 100 \\
III & 100 & 100 \\
\hline
\end{tabular}

Berdasarkan tabel 14 tersebut dapat disimpulkan bahwa perangkat pembelajaran yang dikembangkan sudah efektif, baik karena persentase siswa yang memenuhi kategori karakter tanggungjawab yang diharapkan 'baik' pada setiap pertemuan.

\section{Data Keterlaksanaan RPP}

Data hasil pengamatan keterlaksanaan RPP pada uji coba terbatas dapat di lihat pada tabel 15.

Tabel 15. Hasil keterlaksanaan RPP

\begin{tabular}{lccc}
\hline \multirow{2}{*}{\multicolumn{1}{c}{ Penilaian }} & \multicolumn{3}{c}{ Pertemuan } \\
\cline { 2 - 4 } & I & II & III \\
\hline Terlaksana & 19 & 24 & 25 \\
Tdk terlaksana & 6 & 1 & - \\
$\%$ keterlaksanaan & 76 & 96 & 100 \\
\hline
\end{tabular}

Data Tes Hasil Belajar

Data tes hasil belajar uji coba terbatas diperoleh dari nilai pretest dan posttest control design, sehingga penilaian dilakuakan 2 kali yaitu sebelum diberikan perlakuan (pretest) dan sesudah perlakuan (posttest). Tujuan desain ini adalah untuk mengetahui ada tidaknya pengaruh dan seberapa besar pengaruh perlakuan terhadap peningkatan karakter siswa. 
Tabel 16. Hasil Pretest dan Posttest Uji Coba Lapangan

\begin{tabular}{|c|c|c|c|c|c|}
\hline \multirow{2}{*}{ No } & \multirow{2}{*}{ Nama } & \multicolumn{2}{|c|}{ Nilai } & \multirow{2}{*}{ Indeks Gain } & \multirow{2}{*}{ Kriteria } \\
\hline & & Pretest & Posttest & & \\
\hline 1 & AA & 54 & 84 & 0,65 & Sedang \\
\hline 2 & $\mathrm{AB}$ & 42 & 88 & 0,79 & Tinggi \\
\hline 3 & $\mathrm{AC}$ & 56 & 92 & 0,82 & Tinggi \\
\hline 4 & $\mathrm{AD}$ & 52 & 88 & 0,75 & Tinggi \\
\hline 5 & $\mathrm{AE}$ & 46 & 86 & 0,74 & Tinggi \\
\hline 6 & $\mathrm{AF}$ & 52 & 88 & 0,75 & Tinggi \\
\hline 7 & AG & 68 & 90 & 0,69 & Sedang \\
\hline 8 & $\mathrm{AH}$ & 70 & 96 & 0,87 & Tinggi \\
\hline 9 & AI & 42 & 90 & 0,83 & Tinggi \\
\hline 10 & AJ & 46 & 86 & 0,74 & Tinggi \\
\hline 11 & AK & 56 & 86 & 0,68 & Sedang \\
\hline 12 & $\mathrm{AL}$ & 40 & 78 & 0,63 & Sedang \\
\hline 13 & $\mathrm{AM}$ & 56 & 90 & 0,77 & Tinggi \\
\hline 14 & AN & 50 & 82 & 0,64 & Sedang \\
\hline 15 & $\mathrm{AO}$ & 50 & 84 & 0,68 & Sedang \\
\hline 16 & $\mathrm{AP}$ & 52 & 90 & 0,79 & Tinggi \\
\hline 17 & $\mathrm{AQ}$ & 48 & 86 & 0,73 & Tinggi \\
\hline 18 & $\mathrm{AR}$ & 70 & 86 & 0,53 & Sedang \\
\hline 19 & AS & 56 & 86 & 0,68 & Sedang \\
\hline 20 & AT & 58 & 96 & 0,90 & Tinggi \\
\hline 21 & $\mathrm{AU}$ & 48 & 86 & 0,73 & Tinggi \\
\hline 22 & $\mathrm{AV}$ & 64 & 82 & 0,50 & Sedang \\
\hline 23 & AW & 60 & 82 & 0,55 & Sedang \\
\hline \multicolumn{2}{|c|}{ Total } & 1236 & 2002 & & \\
\hline \multicolumn{2}{|c|}{ Rata-Rata } & 53,74 & 87,04 & & TINCCI \\
\hline \multicolumn{2}{|c|}{ Nilai Tertinggi } & 42 & 78 & $0, / 2$ & IINGUE \\
\hline \multicolumn{2}{|c|}{ Nilai Terendah } & 70 & 96 & & \\
\hline
\end{tabular}

Nilai gain score sebesar 0,72 berarti peningkatan kemampuan siswa termasuk dalam kategori tinggi perbedaan tingkat perubahan kemampuan kognitif peserta didik disebabkan karena perbedaan perangkat pembelajaran yang digunakan.

Dari kedua uji coba yang telah dilakukan kita dapat mengetahui bahwa ada perkembangan yang baik dari uji coba terbatas dengan uji coba lapangan, hal ini dapat kita lihat bersama dari gambar berikut ini:

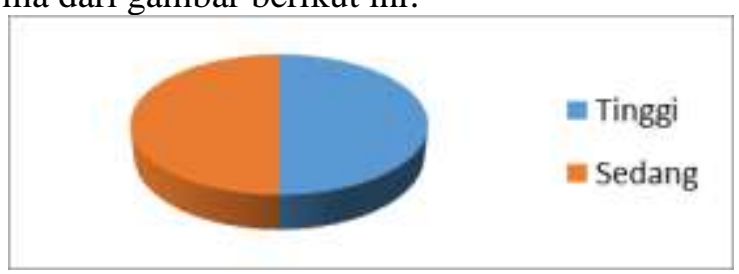

Gambar 5. Hasil Uji Coba Terbatas

Proses pembelajaran dikatakan berhasil jika peserta didik menguasai kompetensi yang telah ditetapkan. Keberhasilan dapat dilihat dari pretest dan posttest yang dihitung dengan gain standar. Peserta didik dikatakan berhasil, jika memiliki nilai posttest yang lebih baik daripada nilai pretest.
Berdasarkan hasil uji coba terbatas yang telah dilakukan, dari 8 subjek uji coba diketahui sebanyak 4 orang mendapat kategori tinggi, dan yang mendapat kategori sedang sebanyak 4 orang.

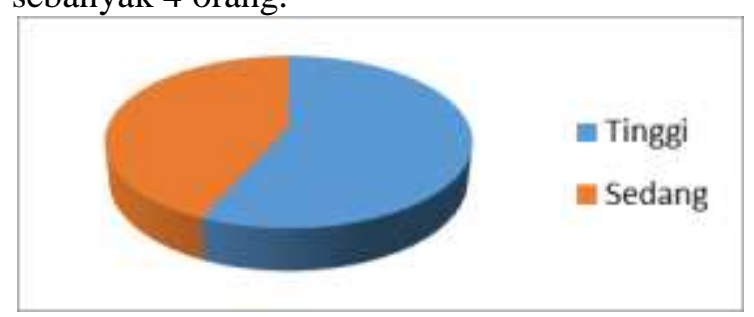

Gambar 6. Hasil uji coba lapangan

Berdasarkan hasil uji coba lapangan yang telah dilakukan, dari 23 subjek uji coba diketahui yang mendapatkan kategori tinggi sebanyak 13 orang, yang mendapatkan kategori sedang sebanyak 10 orang.

Revisi Produk

Berdasarkan penilaian yang diberikan oleh ahli dan data yang didapatkan pada tahapan uji coba, perangkat pembelajaran yang dikembangkan telah dinyatakan memenuhi kualitas berdasarkan kriteria yang telah ditetapkan. Sehingga draft awal yang telah disusun dapat 
dinyatakan sebagai produk akhir. Akan tetapi diperlukan beberapa revisi berdasarkan masukan secara deskriptif yang diberikan oleh ahli.

Revisi yang dilakukan meliputi 3 tahap yaitu revisi draft 1 , revisi draft 2 dan revisi draft 3. Hal ini dilakukan untuk mendapatkan perangkat matematika yang sesuai dengan harapan peneliti dan masyarakat yang menggunakan perangkat matematika tersebut.

\section{Revisi Draft 1}

Berdasarkan saran dan masukan dari validator terhadap perangkat pembelajaran draft 1, maka dilakukan revisi untuk menghasilkan prangkat pembelajaran yang valid. Berikut revisi dari perangkat pembelajaran draft 1:

Pertama, RPP (Rencana Pelaksanaan Pembelajaran), Berdasarkan masukan dari validator baik secara lisan maupun tulisan pada lembar validasi, terdapat beberapa revisi yang harus dilakukan, yaitu: langkah-langkah penyelesaian yang disajikan harus secara runtut, beberapa konsep harus diperbaiki sesuai dengan materi masing-masing, indicator dan tujuan pembel-ajaran di breakdown pada 3 ranah kognitif, afektif dan psikomotorik.

Kedua, Bahan Ajar/Buku Siswa, berda-sarkan masukan dari validator baik secara lisan maupun tulisan pada lembar validasi, terdapat beberapa revisi yang harus dilakukan, konsep maupun redaksi dalam bahan ajar diperbaiki dan bahan ajar sebaiknya dise-suikan dengan pembelajaran joyfull and meaningfull learning serta sejalan dengan kurikulum yang akan datang.

Ketiga, LKS (Lembar Kegiatan Siswa), berdasarkan masukan dari validator baik secara lisan maupun tulisan pada lembar validasi, terdapat beberapa revisi yang harus dilakukan yaitu adanya perbaikan dalam hal redaksi dan konsep matematika, akan lebih baik jika LKS bisa untuk mengukur 3 ranah yang harus dikembangkan.

Keempat, Tes Hasil Belajar, berdasarkan masukan dari validator baik secara lisan maupun tulisan pada lembar validasi, terdapat beberapa revisi yang harus dilakukan, yaitu kalimat yang berada dalam tes hasil belajar kurang tepat, soal dalam pilihan ganda pengecoh sebaiknya disesuaikan dengan cara berpikir siswa, menggunakan bilangan yang lebih sederhana, bahasa yang digunakan bahasa yang mudah dipahami serta kalimat tunggal bukan kalimat jamak.

\section{Revisi Draft 2}

Berdasarkan hasil uji coba terbatas dengan menggunakan perangkat pembelajaran draft 2, maka dilakukan revisi untuk meghasilkan perangkat pembelajaran draft 3 yang akan digunakan pada uji coba lapangan. Berikut ini hasil revisi draft 2:

Pertama, RPP, berdasarkan masukan dari validator baik secara lisan maupun tulisan pada lembar validasi, terdapat beberapa revisi yang harus dilakukan, nilai karakter tidak harus banyak karena akan menjumpai kesulitan dalam melakukan penilaian, menggunakan kalimat praktis, dalam indikator akan lebih baik jika terdapat ranah kognitif, afektif dan psikomotorik.

Kedua, Bahan Ajar/Buku Siswa, berdasarkan masukan dari validator baik secara lisan maupun tulisan pada lembar validasi, terdapat beberapa revisi yang harus dilakukan yaitu redaksi dibenahi ada beberapa yang belum sesuai, diharapkan dalam setiap indicator akan lebih baik jika terdapat ranah kognitif, afektif dan psikomotorik.

Ketiga, LKS, berdasarkan masukan dari validator baik secara lisan maupun tulisan pada lembar validasi, terdapat beberapa revisi yang harus dilakukan redaksi dan konsep perlu dibenahi, dalam setiap indicator akan lebih baik jika terdapat ranah kognitif, afektif dan psikomotorik.

Keempat, Tes Hasil Belajar, berdasarkan masukan dari validator baik secara lisan maupun tulisan pada lembar validasi, terdapat beberapa revisi yang harus dilakukan yaitu pedoman penilaian kurang tepat, dalam setiap indikator akan lebih baik jika terdapat ranah kognitif, afektif dan psikomotorik.

\section{Revisi Draft 3}

Berdasarkan uji coba lapangan, diperoleh bahwa perangkat pembelajaran matematika yang dihasilkan sudah memenuhi kriteria kualitas. Akan tetapi berdasarkan hasil pengamatan di lapangan, dilakukan revisi dari produk yang sudah ada guna menghasilkan produk akhir perangkat pembelajaran matematika yang benar-benar mendukung pembelajaran matematika dilapangan yang menunjang pendidikan karakter.

Pertama, RPP. Masukan dari validator baik secara lisan maupun tulisan pada lembar validasi, terdapat beberapa revisi yang harus dilakukan yaitu tata tulis diperhatikan dengan 
baik, nilai karakter dituliskan dengan huruf miring.

Kedua, Bahan ajar. Secara keseluruhan bahan ajar yang digunakan cukup dapat digunakan dan di respon positif oleh siswa. Revisi hanya dilakukan pada tata tulis pecahan, kalimat yang dipakai masih ada yang belum sesuai dengan tingkat siswa kelas V.

Ketiga, LKS. Secara keseluruhan LKS yang digunakan cukup dapat digunakan dan di respon positif oleh siswa. Revisi hanya dilakukan pada tata tulis pecahan.

Keempat, Tes Hasil Belajar. Masukan dari validator baik secara lisan maupun tulisan pada lembar validasi, terdapat beberapa revisi yang harus dilakukan yaitu kalimat kurang sesuai dengan kondisi siswa kelas $\mathrm{V}$, lembar jawaban belum sesuai dengan petunjuk yang dituliskan pada soal.

\section{Kajian Produk Akhir}

Hasil produk yang berupa perangkat pembelajaran matematika yang menunjang pendidikan karakter telah melewati tahap pendefinisian (Define), perencanaan (design) dan pengembangan (develop) menurut model 4-D Thiagarajan, semmel \& semmel yang telah dimodifikasi menjadi 3-D. Dalam proses validasi ahli pada tahap pengembangan (develop) semua perangkat dinyatakan memenuhi syarat valid. Tujuan dari pengembangan ini adalah untuk mengembangkan perangkat pembelajaran yang menunjang pendidikan karakter pada pokok bahasan pecahan serta untuk mengetahui hasil belajar yang menggunakan perangkat pembelajaran yang beraspek pendidikan karakter. Kualitas perangkat pembelajaran tergambar dari penilaian validator dan keberhasilan perangkat yang dilihat dari tes hasil belajar baik pre-test maupun pos-test yang dilakukan oleh siswa. Beberapa hal yang menjadi temuan dalam penelitian pengembangan perangkat pembelajaran yang menunjang pendidikan karakter, disajikan dalam pembahasan berikut ini:

\section{Kevalidan}

Menurut ahli pendidikan dasar dan pendidikan matematika, hasil pengembangan masuk dalam kategori cukup baik secara keseluruhan menurut ahli perangkat pembelajaran yang menunjang pendidikan karakter pada materi pecahan sudah memenuhi kriteria kelayakan untuk digunakan. Untuk tes hasil belajar dan lembar observasi yang dikembangkan memiliki kategori baik. Sesuai dengan kualitas perangkat yang telah ditetapkan pada bab III bahwa perangkat yang dikembangkan dianggap layak jika aspek yang dinilai mencapai kategori minimal cukup baik.

\section{Kepraktisan}

Pada tahap uji coba terbatas dilakukan penilaian kualitas perangkat pembelajaran yang menunjang pendidikan karakter siswa SD Negeri Lempuyangan 1 dengan materi pecahan. Pada uji coba terbatas pertemuan pertama pembelajaran masih mencapai kategori cukup, hal ini disebabkan karena guru belum terbiasa dengan model pembelajaran STAD dan pada pertemuan berikutnya baru bisa mencapai kategori baik karena sudah dapat menggunakan dengan baik dalam proses pembelajaran. Pada uji coba terbatas ini dilakukan penilaian keterbacaan perangkat pembelajaran. Hasil penilaian guru menunjukkan bahwa perangkat pembelajaran yang dikembangkan dalam kategori baik.

\section{Keefektifan}

Proses pembelajaran yang dilaksanakan di dapat beberapa temuan diantaranya adanya peningkatan hasil belajar. Penggunaan perangkat pembelajaran yang dikembangkan memberikan hasil yang lebih baik terhadap peningkatan hasil belajar siswa. Hal ini dikarenakan dalam proses pembelajaran matematika dengan menggunakan perangkat yang menunjang pendidikan karakter, siswa belajar secara berkelompok, berdiskusi, dan mengembangkan ketrampilan atas dasar pemahaman yang dapat membuat siswa aktif membangun dan menemukan sendiri pengetahuannya sehingga proses pemahaman konsep lebih mudah diinternalisasikan ke dalam konteks dunia nyata. Situasi belajar diharapkan dapat menumbuhkan pada diri siswa untuk berlaku jujur, disiplin dan tanggung jawab. Hasil penelitian ini senada dengan apa yang disampaikan oleh Bell (1981, p. 253) bahwa aktivitas dalam kelompok tidak hanya membantu siswa untuk mengetahui, memahami fakta dan mendapatkan ketrampilan, tetapi juga diarahkan untuk menganalisis, mensistesis dan mengevaluasi konsep dan prinsip, bahkan memungkinkan untuk lebih membedakan pada penekanana tujuan afektif yang sesuai dengan tanggung jawab, pilihan nilai-nilai, konseptualisasi nilai, dan pengorganisasian nilai. Hal yang sama menurut Zakaria \& Ikhsan (2007, p.35) bahwa pembelajaran kooperatif menjadi dasar yang dipercayai bahwa pembel- 
ajaran paling efektif ketika peserta didik aktif dalam berbagi dan bekerja sama menyelesaikan tugas akademik.

Karakteristik lain dari perangkat pembelajaran yang menunjang pendidikan karakter dengan materi pecahan mempunyai beberapa keunggulan yang dimiliki, yaitu RPP merupakan hasil pengembangan, Bahan ajar dan LKS yang dikembangkan sangat menarik perhatian peserta didik sehingga ada kemauan untuk belajar serta memuat cerita atau kata mutiara yang mengandung nilai karakter jujur, disiplin dan tanggungjawab. Selain ada keunggulan pastilah ada kekurangannya, yaitu hanya mencakup satu materi pecahan, dan nilai karakter yang dikembangkan berjumlah tiga padahal karakter yang ada mencapai 18 karakter yang semuanya sebenarnya bisa dikembangkan pada semua materi.

Berdasarkan hasil kajian akhir tersebut dapat diperoleh informasi bahwa kualitas perangkat pembelajaran yang terdiri dari RPP, Bahan ajar/buku siswa, LKS dan tes hasil belajar yang dikembangkan telah layak digunakan dalam pembelajaran matematika tingkat sekolah dasar kelas $\mathrm{V}$.

\section{Simpulan dan Saran}

Simpulan

Berdasarkan hasil penelitian dan analisis data maka diperoleh kesimpulan dalam penelitian pengembangan ini sebagai berikut: (1) kualitas hasil akhir produk yang dikembangkan berupa (a) RPP (Rencana Pelaksanaan Pembelajaran), terdiri dari 1 RPP untuk 3 kali pertemuan, termasuk dalam kategori cukup baik, (b) bahan Ajar/Buku Siswa, terdiri dari 3 sub termasuk kategori baik, (c) LKS (Lembar Kegiatan Siswa), terdiri dari 3 sub LKS untuk 3 kali pertemuan, termasuk kategori baik, (d) Tes Hasil Belajar, terdiri dari 10 soal pilihan ganda dan 5 soal uraian disertai kisi-kisi, lembar jawaban, kunci jawaban dan pedoman penskoran, termasuk kategori baik; (2) Perangkat pembelajaran matematika yang menunjang pendidikan karakter yang dihasilkan masing-masing termasuk ke dalam kategori efektif dilihat dari hasil belajar siswa; (3) Karakter kejujuran, kedisiplinan dan tanggungjawab dapat menalami peningkatan dengan baik melalui pembelajaran matematika materi pecahan; (4) Keterlaksanaan perangkat pembelajaran matematika yang menunjang pendidikan karakter siswa kelas $\mathrm{V}$ sekolah dasar yang di uji cobakan secara terbatas dan lapangan dapat terlaksana dengan baik.

Saran

\section{Saran Pemanfaatan Bagi Guru}

Adapun saran dalam pemanfaatan produk pengembangan perangkat pembelajaran matematika ini bagi guru adalah perangkat pembelajaran hasil pengembangan diharapkan dapat digunakan oleh pendidik dalam proses pembelajaran untuk pembentukan karakter siswa kelas $\mathrm{V}$ sekolah dasar dan dapat mengembangkan perangkat pembelajaran yang dikembangkan pada materi yang berbeda, menggunakan model pembelajaran yang berbeda dan pada tingkat kelas yang berbeda pula.

\section{Saran Pemanfaatan Bagi Instansi terkait}

Saran pemanfaatan bagi instansi adalah ketika melakukan proses pembelajaran dengan menggunakan Kepada Dinas Pendidikan agar dapat mendeseminasikan perangkat pembelajaran hasil pengembangan ke kecamatan yang lain, tidak hanya pada sekolah yang diuji cobakan.

\section{Daftar Pustaka}

Bell, F.H. (1981). Teaching and learning mathematics (in secondary school). Second Printing, Dubuque, Iowa: Wm.C. Brown Company Publisher.

Borg, W.R \& Gall, M.D. (1983). Educational research: an introduction. New York: Longman

Cohen, J. (2006) Social, emotional, ethnical and academic education: creating, climate for learning, participation in democracy and well being. Harvard education review, vol. 71 No. 2 summer 2006.

Hake, R.R. (1998). The need for improved physics education for teachers: fci pretest score for graduates of highschool physics courses is it finally time to implement curriculum. American journal of physics, 66.

Lickona, T. (1991). Educating for character: How our schools can teach respect and responsibility. New York: Bantam books.

Republika Online http://www.republika.co.id/ berita/breakingnews/nusantara/10/12/19 /153158-waduh-anak-sdpun-sudahberani-bunuh-diri 
Republik Indonesia, (2003). Undang-undang No. 20 tahun 2003 tentang sistem pendidikan nasional.

Sukardjo. (2005). Evaluasi pembelajaran. Diktat mata kuliah evaluasi pembelajaran. Prodi Tehnologi P PPs UNY. Tidak diterbitkan.

Supriadi Dwi. (2010). Pendidikan berketeladanan. Diambil pada tanggal 17 September 2012 dari http://edukasi.kompasiana.com/2012/08 /24/pendidikan-berketeladanan/
Thiagarajan, S., Semmel, D.S., and Semmel, M.I. (1974). Instructional development for training teachers of exceptional childreen. Leadership training institute/special education, Minnesota: University of Minnesota, Minneapolis.

Zakaria, Effandi \& Iksan, Zanaton. (2007). Promoting cooperative learning in science and mathematics education: A Malaysian Perspective. Eurasia journal of mathematics, science \& technologi education, 3 (1). 